\title{
Using a Suggested Web-Based Learning Program in Developing EFL Listening Skills of the First-Year Secondary Students
}

\author{
Hussein Taha Atta Salem ${ }^{1}$, Mohammed Safwat Hassan², Mahmoud El-Dabea Abdel-Kareem ${ }^{3}$ \\ ${ }^{1}$ Faculty of Education, Sohag University \\ ${ }^{2}$ New Valley Faculty of Education, Assiut University \\ ${ }^{3}$ El-Wakada Preparatory \& Secondary Institute for Girls
}

\begin{abstract}
The current research attempted to investigate the effect of using a suggested web-based learning program on developing EFL listening skills of the first-year secondary students. To achieve this purpose, the researchers constructed and validated a web-based learning program, a listening skills test. Using the quasi-experimental method, a randomly chosen sample of fifteen first-year secondary students at El-Botakh Secondary School was pre-tested using the listening skills test. Then they were engaged in the program. By the end of the program, they were post-tested using the same instrument utilized earlier. The results revealed that the web-based learning program was effective in developing their listening skills. These findings may serve as suggestions for English teachers who intend to benefit from web-based learning.
\end{abstract}

Keywords: Web-based learning, listening skills.

\section{Introduction}

Modern trends in education have witnessed a shift in focus from teachercentered to learner-centered education and an increase in the use of Web-based learning tools which provide integrated environments of various technologies to support diverse educators' and learners' needs via the internet. Modern teaching programs are based on learner-centered principles and reflect the need for appropriate use of Webbased learning environments.
The demand for web-based language learning has increased and online technologies have contributed notably to language education and e-learning technologies can be used to teach English. WBLL is learning language through the use of the Web and exploiting Web materials, resources, applications or tools (Son, 2007).

A Web-based learning environment is available at any time and any place. The learning environment can be accessed by a 
large, distributed and diverse group of students. The learning environment may be monitored by the educator to ensure a safe learning experience for the students. The students can be provided with many different resources in a variety of interactive and multimedia formats. These may be designed to allow active participation in learning and facilitate the individual construction of knowledge (Callahan et al, 2013).

Web-based learning provides activities, learning materials, and learning environment which contribute positively to learning a language and developing language skills. Web-based language learning depends on the Web which can support language teachers to integrate Web resources into the language classroom (Son, 2007). It can be also a virtual library that has a huge amount of information valuable to English as a second language (ESL) teaching (Murray \& McPherson, 2004). In addition, Web-based language learning (WBLL) has the potential to increase learner motivation and engage learners in culturally authentic and highly interactive language experience (Kung \& Chuo, 2002).

The need for using modern technology and web tools in teaching Listening stems from the importance the listening skill among other language skills. Rost (2002) mentioned that listening is the most critical skill for language learning at the beginning stages. Schilling (2002) assured that listening is an essential skill at work and at home. At work, it reduces errors and wasted time. At home, it develops resourceful, self-reliant kids who can solve their own problems. El Keles (2003) pointed that listening is as important as speaking in face-to-face communication. Al-Hariree (2004) affirmed that listening is identified as a fundamental aspect in the language classroom because it provides an input for the learner. Without understanding this input at the right level, any learning simply cannot begin. Arnold (2005) referred that listening provides a foundation for all aspects of language and cognitive development and it plays a life-long role in the processes of learning and communication.

Many researchers assured that foreign language learners have some listening problems. These problems are usually attributed to the speed of delivery of the listening text, lack of exposure to fluent natural speech, and encountering new terminology and vocabulary (Hasan, 2000; Graham, 2006).It is, also, proved that the use of technology in language learning can impact positively on listening skills. Beare (2008) pointed out the increased use of multimedia and Internet and the numerous 
new edge websites that are constantly being developed. Some of these websites offer a variety of short video clips available for easy access. Batra (2008) assured one of these popular technologically provided sites is YouTube where video clip sharing has made it an influential power one that contributes to a revolution in varied realms, including language learning.

Vo (2013) assured that students can improve their listening skill with Internet recourses. He used some internet resources to develop extensive listening for EFL learners. The positive results due to the advantages of internet recourses e.g. learners had opportunities to listen to what they desired to listen to at their language level. They shared with their classmates about what they learned and supported each other through peer or group work.

Pala (2005) constructed a web-based beginner, intermediate, and advanced level activities to develop listening and reading skills for students learning Turkish in the English-speaking world and improved them according to feedback received from selfstudy students as well as Turkish language instructors. He assured the effectiveness of web-based activities in developing reading and listening skills.

\section{Background of the problem}

Although listening is a very important language skill, it is neglected in classrooms and learners face a lot of problems. Abdel Latif (2002) assured that listening is one of the least stressed skills in language teaching and learning. It receives less attention and less class time. Bear (2004) pointed out that teachers rarely teach listening in classrooms as they think that listening develops automatically and naturally over time.

Al-Hariree (2004:1) affirmed that teachers spent most of their teaching time working with their students on reading and writing activities and sometimes speaking. According to Tompkins $(2005: 293)$ the skill of listening has been largely ignored in mainstream curriculum for a long period because a number of educators have paradoxical notions: "Children come to school already knowing how to listen," and focus must be placed on "reading and writing instruction" (not listening) in order to enhance students' ability in language learning.

Soliman (2012) concluded that teachers do not have time to do much more than see if the students got answers right or wrong and no time is spent on finding out why and where they went wrong. Teachers do not teach listening in the right way. El Tawila 
(2009) assured that listening skills were neglected in the Egyptian preparatory schools. He conducted his study in La Seifer Preparatory School in Tanta to explore the reasons for the neglect of listening by Egyptian English Language Teachers. He found that students didn't like listening lessons because they were taught in a way lacking attraction and exams didn't concentrate on listening skills.

The above studies assured that there are problems in teaching listening skills, some of the problems related to the ways teaching listening. Others related to the teachers and the curriculum. The researchers visited some secondary classrooms and interviewed some teachers and students. He noticed that: listening skills are not given adequate consideration. Moreover, procedures and techniques used in some classrooms are not adequate to develop listening skills.

The researchers asked a number of secondary-school teachers which listening skills were problematic and needed to be developed. They mentioned that the most problematic listening skills were (listening for specific information, listening to guess the meaning of new words from the listening context, listening to make inferences, listening to identify the main idea in the spoken discourse, and listening to recognize the letter sound association (phonemegrapheme relationship) ). To make sure that these skills were problematic, the researcher tested 15 first-year secondary students, randomly selected from El-Botakh Secondary School, in listening skills. The test aimed at evaluating first-year secondary students' listening skills. The test concentrated on the skills of listening for specific information, listening to guess the meaning of new words from the listening context, listening to make inferences, listening to identify the main idea in the spoken discourse, and listening to recognize the letter sound association (phoneme-grapheme relationship). The test consisted of four listening texts and two types of questions: multiple choice and Wh. questions. On analyzing the results of the test, the researcher could conclude the following results: 
Table (1) Students' scores in the Pilot Listening Skills Test

\begin{tabular}{|c|c|c|}
\hline Listening skills & $\begin{array}{c}\text { From } 5 \text { marks to } \\
10 \\
\end{array}$ & $\begin{array}{c}\text { From } 0 \text { to } \\
5\end{array}$ \\
\hline 1.listening for specific information & $40 \%$ & $60 \%$ \\
\hline $\begin{array}{l}\text { 2. Listen to guess the meaning of new words from the } \\
\text { listening context }\end{array}$ & $47 \%$ & $53 \%$ \\
\hline 3.Listen to make inferences & $8 \%$ & $92 \%$ \\
\hline $\begin{array}{l}\text { 4. Listen to identify the main idea in the spoken } \\
\text { discourse }\end{array}$ & $14 \%$ & $86 \%$ \\
\hline $\begin{array}{l}\text { 5.Listen to recognize the letter sound association } \\
\text { (phoneme-grapheme relationship) }\end{array}$ & $20 \%$ & $80 \%$ \\
\hline
\end{tabular}

Data presented in the above table revealed that $60 \%$ of the students were weak in listening for specific information. $53 \%$ of the students were weak in listening to guess the meaning of new words from the listening context. $92 \%$ of the students were weak in listening to make inferences. $86 \%$ of the students were weak in listening to identify the main idea in the spoken discourse. $80 \%$ of the students were weak in listening to recognize the letter sound association. These results revealed that these skills need to be developed.

\section{Purpose of the study}

More specifically this study attempted to explore the effect of using a suggested webbased learning program on the first-year secondary students' EFL listening skills.

\section{Question of the study}

The present study attempted to find an answer to the following question:
What is the effect of a suggested web-based learning program on developing the first-year secondary students' EFL listening skills?

\section{Hypothesis of the study}

The current study attempted to test the following hypothesis:

"There is a statistically significant difference at $(0.05)$ level between the mean scores of the first-year secondary students on the preapplication and the post-application of the EFL listening skills test in favor the postapplication".

\section{Delimitations of the study}

This study was delimited to:

1. Fifteen first-year secondary students randomly selected from El-Botakh secondary school in El-Maragha, Sohag where the researcher lives and works.

2. Some listening skills according to the experts' views: (Listening to guess the meaning of new words from the listening context/ listening for specific 
information/ listening to identify the main idea in the spoken discourse/ listening to recognize the letter sound association/ listening to make inferences). These skills are chosen because they are suitable for first-year secondary Students and they can be taught electronically.

\section{Significance of the study:}

The significance of this study stems from the following considerations:

1. Developing EFL listening skills among first-year secondary school students is expected to positively affect their performance in other language skills as they become more proficient in the use of their language.

2. Helping EFL teachers and curriculum designers to prepare modules and activities depending on web-based learning to develop language skills (listening, speaking, reading, and writing).

3. Drawing attention to the listening skills which may need to be developed in the secondary stage.

\section{Review of Literature}

\section{The Importance of Web-Based Learning:}

The importance of Web-based learning stems from the advantages which are shown by many researchers. Chang (2001) constructed and evaluated a web-based learning portfolio (WBLP) of authentic assessment. The results of the system evaluation show that most students consider the system to be helpful with respect to improving learning and accomplishing quality.

Chumley-Jones, et al (2002) assured that web-based learning is advantageous and effective in the teaching-learning process. Callahan et al (2013) designed web-based curriculum materials to help social studies teachers develop their professional teaching knowledge. The Web-based social studies curriculum was effective.

The web-based learning environment has some advantages such as stretching the spatial and temporal barriers, flexibility, interactivity and interoperability (Kinshuk \& Yang, 2003). It provides new potential to enhance learning through a visual and interactive delivery of instruction. When the web is employed for instructional delivery, it can provide learners with a variety of diverse internet resources without the constraint of time and place; learners can thus search a wealth of relevant information. It helps students possess self-regulatory skills to guide their discovery and learning (Lee \& Baylor, 2006). Web technologies such as YouTube, podcasts, blogs, discussion groups, 
forums etc. provide many possibilities for engaging students in desirable practices (Duffy, 2008). Students can access the learning materials and tasks both at the teaching institution (school or university) or at home and at any time of the day (Almekhlafi, 2006).

Web-based learning provides no time and space limit, synchronous and asynchronous communication. It provides flexibility in teaching and learning, free from the physical boundaries of classrooms and the time restraints of class schedules. Added to this, lectures, lessons and demonstrations are possible through Web-based multimedia learning experiences for students (Al-Jarf, 2000). It saves costs in travel, housing, building new schools, and instructors' salaries. It provides self-spaced learning (Menager-Beeley, 2001). The Web enhances learning environments as well as interactive environments to shy students who do not dare to speak in class, but that are willing to chat real time with other students around the world. Students acquire some communicative skills students acquire through the web. They have opportunities of negotiating, persuading, clarifying meaning, requesting for information, exchanging ideas, discussing, asking questions, etc. (Moras, 2001).
Web-based learning links resources in many different formats. It is an efficient way of delivering course materials. Its resources can be made available from any location and at any time. It encourages more independent and active learning and provides source of supplementary materials. Students receive quick feedback and computer marking is an efficient use of staff time (Mckimm et al, 2003). It allows students to progress at their work individually and to meet their teachers in one-one sessions. Many web-based learning packages are offered in modules, which students work through individually, at their own pace (Stennes, 2012). In addition, the resources of the World Wide Web are unlimited, and the advantages it provides for language learners are tremendous. For example, students can publish their texts or multimedia materials, and these can be shared with partners or any other individual around the world (Warschauer \& Kern, 2005).

Teachers' role is a consultant, a guide, a coach and a resource provider. Teachers become expert questioners, rather than providers of answers; teachers provide structure to student work, encouraging selfdirection; a shift of teachers from total control of the teaching environment to sharing with the student as fellow learner. 
Learners' role is to construct their own knowledge, put hands into complex problemsolving activities. They become autonomous, independent, self-motivated managers of their time. They choose materials depending on their personal academic progress. In short, teacher-learner hierarchy is broken down (Berge, 2000).

Students also expressed satisfaction with the immediate online feedback that they received after doing their assignments and/or homework (Zapata \& Sagarra, 2007). Online feedback, whether explicit or implicit (e.g. recasts), is a good motivation for students to develop their language and learn from their mistakes. Students are grateful for being corrected because that eventually helped them to avoid making the same mistakes and to improve in various language skills (Deckhinet, 2008).

\section{Web-based learning and listening}

A number of researchers (Jones, 2003; Wong, 2005; Beare, 2008) have conducted studies on the relationships between listening skills and uses of technology in language learning. In these studies, a majority of findings and results presented positive interactions. They pointed out the increased use of multimedia and Internet and the numerous new edge websites that are constantly being developed. Some of these websites offer a variety of short video clips available for easy access. One of these popular technologically provided sites is YouTube where video clip sharing has made it an influential power (Cass, 2007; Badal, 2008; Batra, 2008), one that contributes to a revolution in varied realms, including language learning.

Vo (2013) assured that students can improve their listening skill with Internet recourses. He used some internet resources to develop extensive listening for EFL learners. The positive results due to the advantages of Internet recourses e.g. learners had opportunities to listen to what they desired to listen to at their language level. They shared with their classmates about what they learned and supported each other through peer or group work.

\section{Participants of the Study}

A first-year class from El-Botakh Secondary School, one of the public schools in Sohag Educational Directorate, was randomly selected to participate in the experiment. Reviewing the school records, their ages were ranged from fifteen to sixteen years old. They studied English for nine years, beginning in primary one. They all live in Sohag Governorate with similar socio- 
cultural backgrounds. Despite the availability of both genders at the same school, boys were chosen to get involved in the experiment because they showed readiness to participate and it was easy to communicate with them at any time.

\section{Design of the Study}

The one group pre-posttest design was used in this study which involved only one group of participants to whom some treatment was given. They were first pretested using the EFL Listening Skills Test. After administering the suggested program, the participants were post-tested utilizing the same instrument above, and then the results were compared.

\section{The Suggested program}

This program was web-based learning program in which students were exposed to learner-centered activities where they are encouraged to construct their knowledge and to control their learning with the help and guidance of their teacher. It was designed to provide them with a variety of opportunities to develop their listening skills benefitting from web materials such as YouTube videos, teaching listening sites, and Facebook. Each module was divided into three steps: prelistening stage (included warm-up exercises and activities), while-listening stage (included the two parts of the listening lesson), and post-listening stage (included evaluation and free learning on the web).

\section{Designing the program}

To build the program, the researchers followed the procedures below:

\section{a. Preparing an EFL listening skills checklist}

To identify the EFL listening skills needed to be acquired by first-year secondary students, a checklist was designed and submitted to a jury of faculty members. They determined the most necessary skills for first-year secondary students. The researcher chose the first five (Listen to guess the meaning of new words from the listening context, Listen for specific information, Listen to identify the main idea in the spoken discourse, Listen to recognize the letter sound association, and Listen to make inferences) to be developed by the program because the teachers previously assured their importance.

\section{b. Selecting the topics of the modules}

The topic of the listening script of each module was selected from the students' books (Haines \& Dallas, 2014) issued by the Ministry of Education for the secondary stage (year 1, year 2, year 3). The passages were modified and adapted to suit the learners. Phobias, Bird flu, Sports, Computer, and 
Global warming were the topics selected because they were suitable for students' levels and the time of the module.

\section{c. Selecting YouTube videos and listening websites checklist}

To select and evaluate the most appropriate YouTube videos and listening websites to be included in this program, a checklist was designed and submitted to a jury of faculty members. They determined the most appropriate ones according the following criteria: (Authenticity/ Appropriateness/ Currency and accuracy/ Relevance to the topics of the program/ Presentation and engagement).

\section{d. Building a framework for the program} Having the listening skills defined, a framework for the program was designed including objectives of the course, content, number of modules, the division of each module, duration of the sessions, and the new vocabulary.

\section{e. Setting up the website}

The researchers designed the website form and the scenario and the steps to follow up and progress in the site. The researchers chose the URL of the website, decided the passwords and user names. Instructions were included in the site to make it user-friendly. Pictures, multimedia, and attractive colors were used to motivate the students. The website design was submitted to a jury of faculty members and it was modified according their opinions.

\section{f. Preparing a print out for the teacher}

To tell the teacher everything about the program, a printout was prepared. It included the teacher role in the program, scope and sequence of the program, objectives of the program, how to use the program, the duration of the program.

\section{g. Validating the program}

To judge the validity of the program, it was submitted to a jury of faculty members to decide: (The pertinence of the behavioral objectives of every module to the general aims of the program/ The suitability of topics and content areas to the program objectives and aims/ The appropriateness of the activities, exercises and evaluation means to achieve the objectives/ The clarity of the instructions).

The jury members found the program as a whole well-prepared and suitable for the purpose it was designed for. However, they suggested some modifications to make it more applicable: (Modifying the form of the website design/Adding a dictionary/Adding more pictures/Modifying the time of the parts 
of the modules/Adding some instructions to the teacher and the learner).

The program became ready for piloting and implementation after these recommendations and suggestions mentioned above had been taken in consideration in the final version of the program.

\section{Piloting the Program}

\section{Objectives of Piloting the Program:}

The program was piloted to determine:(The suitability of the timing of the various activities and exercises of every session in every module as well as the program as whole/ The applicability of the activities and exercises for online-learning/ The suitability of the program content for the first-year secondary students/The clarity of instructions included in the program/ Technical problems and difficulties that may arise when using the website and solutions that can be suggested to solve them).

To achieve these objectives, two modules (Module One: Phobias \& Module Two: Bird Flu) of the program were administered to a randomly-selected sample of 15 boys, excluded from the main experiment, from amongst the first-year secondary school students at El-Botakh Secondary School for two weeks.

\section{Evaluating the Pilot Study of the Program}

One of the measurement approaches able to provide critical information about the program as a process is formative evaluation. It is conducted during the development or delivery of a program to make adjustments on the fly for improvement. It is based on the observations of the researcher as well as the feedback received from students. Using this type of evaluation, the following modifications were made in the final form of the program:

1. Based on the students' feedback, the instructions of using the website were not clear enough so the researcher added some print screens of the website.

2. Students' faced some problems in finding the meaning of some words so the researcher added an online dictionary (https://translate.google.com.eg) to the website.

3. Warm up session was not very exciting and attractive because the material was just URL (the address of webpage) so the researcher added the videos to the material.

4. In activity 4, 5, and 6; students wasted a lot of time to listen to the whole listening script so the researcher divided it into segments. 
5. It was planned that students and their teacher could communicate via Facebook but some of them didn't have accounts, others had problems with it. Accordingly, a discussion group was added to the website.

Another type of evaluation which primarily aims to get the total picture of the quality and effectiveness of the produced program is summative in its nature.
For that purpose, an evaluation sheet was constructed and validated by a jury of faculty members. The pilot study evaluation sheet was then submitted to the students to get their opinions about the modules they studied during the pilot study. It was translated into Arabic to be easy for the students to understand it. Students' answers were scored and tabulated as shown in the following table (2).

Table (2) The Summative Evaluation Results of Piloting the program

\begin{tabular}{|c|c|c|c|c|}
\hline Statement & Agree & Not Sure & Disagree & Ratio of \\
\hline 1. The program helped me improve my Ability to listen & 18 & 1 & 1 & $90 \%$ \\
\hline 2. The program content was relevant to my interests & 19 & 1 & - & $95 \%$ \\
\hline 3. The program content was appropriate for my needs & 16 & 2 & 2 & $80 \%$ \\
\hline 4. The program content was compatible with my level & 17 & 2 & 1 & $85 \%$ \\
\hline 5. The way of teaching the program was interesting & 20 & - & - & $100 \%$ \\
\hline 6. The time allocated for the program was enough & 15 & 3 & 2 & $75 \%$ \\
\hline 7. The activities and exercises were various & 18 & 2 & - & $90 \%$ \\
\hline 8. The instructions of the program were clear & 13 & 5 & 2 & $65 \%$ \\
\hline 9. The videos and the suggested websites were suitable & 14 & 6 & - & $70 \%$ \\
\hline $\begin{array}{l}\text { 10. The sound of the listening scripts was clear and easy } \\
\text { to follow }\end{array}$ & 19 & 1 & - & $95 \%$ \\
\hline $\begin{array}{l}\text { 11. The time I spent in the study of the program was } \\
\text { fruitful }\end{array}$ & 20 & - & - & $100 \%$ \\
\hline 12. I 'd like to participate in similar programs & 20 & - & - & $100 \%$ \\
\hline
\end{tabular}

It is obvious from the data presented in the table above that students' input concerning different dimensions of the program was positive. This is clearly indicated in the high ratio of agreement on all the statements of the evaluation sheet. However, the researcher increased the time of the program, simplified the instructions of the program to be clearer and replaced some videos and websites with more suitable ones.
After validating, piloting, and making use of the information collected to modify and improve it, the program became ready to be implemented in the main experiment of the research.

\section{Instruments of the Study}

The researcher constructed and adapted the following instruments:

\section{The Listening Skills Test}




\section{Aim of the Test}

The test was designed to assess the effect of suggested Web-Based Learning Program on developing EFL listening skills of the firstyear secondary students. More specifically, the test was used to see the amount of improvement that might happen as a result of administering this program.

\section{Description of the Test}

The test consisted of five parts, each part tested one of the research five listening skills and included three items as follows:

Table (3) Parts of the listening skills test

\begin{tabular}{c|c}
\hline Skills & Tart 1: \\
\hline \hline $\begin{array}{c}\text { To test the skill of and choose the right } \\
\text { meaning: Guessing the meaning of the new } \\
\text { words from their context. }\end{array}$ & $\begin{array}{c}\text { Listen to the conversation between } \\
\text { Sara and Lisa and choose the right } \\
\text { meaning. }\end{array}$ \\
\hline $\begin{array}{c}\text { Part 2: } \\
\text { To test the skill of and choose the right words } \\
\text { Listening for specific } \\
\text { Information }\end{array}$ & $\begin{array}{c}\text { Listen to the conversation between Ms. } \\
\text { Nancy and Soha and choose the right } \\
\text { words to complete the sentences. }\end{array}$ \\
$\begin{array}{c}\text { Part 3: } \\
\text { To test the skill of Identifying the Main Idea } \\
\text { the Spoken Discourse }\end{array}$ & $\begin{array}{c}\text { Listen and choose the right main idea. } \\
\text { Part 4: }\end{array}$ \\
$\begin{array}{c}\text { To test the skill of Recognizing the letter } \\
\text { sound association (phoneme-grapheme } \\
\text { relationship) }\end{array}$ & $\begin{array}{c}\text { Listen to the conversation between a } \\
\text { seller and Marianne and choose the } \\
\text { word you and hear in the listening } \\
\text { text. }\end{array}$ \\
$\begin{array}{c}\text { Part 5: } \\
\text { To test the skill of Making inferences }\end{array}$ & $\begin{array}{c}\text { Listen to the conversation between a } \\
\text { "Totel Clerk and Mr. Edwin and click } \\
\text { sentence is true and "F" } \\
\text { if the sentence is false. }\end{array}$ \\
\hline \hline
\end{tabular}

\section{Scoring technique of the Test}

Reviewing pertinent literature (e.g., Abdelhafez, 2006; SZE, 2006; Hayati, 2010 ; Amin et al., 2011; Ghaderpanahi, 2012; Sabet \& Mahsefat, 2012; Mousavi \& Iravani, 2012; Vo, 2013;), the researcher prepared an analytical detailed rubric to evaluate students' performance in the pre-post EFL Listening Skills Test. Their answers on the test were scored out of 30 . Six marks for each part and two marks for each item.

\section{Validity of the Test}

To ensure the validity of the listening skills test, the researcher submitted it in its initial form to a jury of TEFL faculty members and specialists to decide on: (The suitability of the listening texts to students' level/ The suitability of the items to the stated skills of the test/ The Sufficiency of the items to cover the identified skills/ The clarity of the test instructions). 
In general, the jury members appraised the test and its scoring rubric as being valid, clearly stated, and suitable for the purpose they were designed for and students' level of performance in English. The selected listening texts were also approved to be appropriate for assessing students' listening skills. Yet, they suggested some modifications; for example, specifying the test duration, restating some sentences.

\section{Piloting the test}

After modifying the test according to the jury members' comments, it was piloted on a randomly-selected sample of 15 boys from a class of 25 students, excluded from the main experiment, from amongst the first-year secondary school students at El-Botakh Secondary School to determine its duration, validity of the test consistency and test reliability.

\section{a. Duration of the test}

Duration of the EFL Listening test was estimated by calculating the time spent by the first student added to the time taken by the last student in answering the test, and then the two periods were averaged. The time allotted was "50" minutes.

\section{b. Internal Consistency of the test}

The Internal Consistency of the EFL Listening Skills Test was calculated and the results were shown in Table (4) and Table (5) below:

Table (4) Correlation coefficients between the Test items and the total sum

\begin{tabular}{c|c|c}
\hline \hline Item & Correlation coefficient & significance \\
\hline 1 & $0.519^{* * *}$ & significant \\
\hline 2 & $0.561^{* *}$ & significant \\
\hline 3 & $0.432^{* *}$ & significant \\
\hline 4 & $0.582^{* *}$ & significant \\
\hline 5 & $0.657^{* *}$ & significant \\
\hline 6 & $0.597^{* *}$ & significant \\
\hline 7 & $0.548^{* *}$ & significant \\
\hline 8 & $0.590^{* *}$ & significant \\
\hline 9 & $0.593^{* *}$ & significant \\
\hline 10 & $0.657^{* *}$ & significant \\
\hline 11 & $0.746^{* * *}$ & significant \\
\hline 12 & $0.405^{*}$ & significant \\
\hline 13 & $0.504^{* *}$ & significant \\
\hline 14 & $0.593^{* *}$ & significant \\
\hline 15 & $0.590^{* *}$ & significant \\
\hline \hline
\end{tabular}


It is noted from the previous table that all the correlation coefficients of the test items were significant at the level of (0.05) or level of (0.01), indicating that the test has an appropriate degree of validity.

Table (5) Correlation coefficients between the Test parts and the total sum

\begin{tabular}{c|c}
\hline \hline Test parts & total \\
\hline 1 & $0.813 * *$ \\
\hline 2 & $0.897 * *$ \\
\hline 3 & $0.861 * *$ \\
\hline 4 & $0.815 * *$ \\
\hline 5 & $0.836 * *$ \\
\hline \hline
\end{tabular}

\section{c. Reliability of the Test}

To establish the reliability of the EFL Listening Skills, Test-Retest method was used and estimated by IBM SPSS, Version 22.0. The 20 students of the pilot study performed the test twice. The time between the two administrations was two weeks. The researcher utilized Cronbach's Alpha and the results were shown in Table (6) and Table (7):

Table (6) Reliability Statistics

\begin{tabular}{c|c}
\hline \hline Cronbach's Alpha & N of Items \\
\hline 0.701 & 15 \\
\hline \hline
\end{tabular}

Table (7) Reliability Statistics

\begin{tabular}{c|c}
\hline \hline Guttman Split-Half Coefficient & N of Items \\
\hline 0.882 & 15 \\
\hline \hline
\end{tabular}

It is clear from the two previous tables that the test has a high degree of reliability, where the value of the Alpha coefficient of reliability was 0.701 , and the value of the reliability coefficient of re-test was 0.882 .

After administering the main experiment, the data obtained were analyzed to find answers to the questions of the current research using the following two software programs:

\section{Procedures of the Experiment}

To conduct the experiment of this research, the procedures below were followed:

1. On March 5, 2017, the current research group was randomly selected from amongst the boy classes of the first-year secondary school students at El-Botakh Secondary School. Then, the participants were introduced to the program and its valuable benefits for their study in general, and developing their listening skills.

2. On March 8 and 9, 2017, the participants were pre-tested using the prepared research instruments; i.e., the EFL listening skills test.

3. An introductory session was held on March 12, 2017 to give the students their usernames and passwords and the URL required to use the website (www.listenonweb.com). Using the interactive board, the researcher showed them how to use the website. 
4. Actual application the suggested program began on March 13, 2017 and continued till May 29, 2017.

\section{Findings}

\section{Firstly, Testing the Hypothesis}

\section{The Question of the Study}

The question of the research was stated as follows:

"What is the effect of a suggested web-based learning program on developing the first-year secondary students' EFL listening skills?" To answer this question, it was hypothesized that:
"There is statistically significant difference at (0.05) level between the mean scores of the research group (the first-year secondary students) in the pre-test and the post-test on the EFL listening skills test (in favor the post-test)."

To test this hypothesis, the students' scores on the EFL Listening Skills Test were first calculated and tabulated Wilcoxon Test was then employed and the results were shown in the table (8) below:

Table (8) Results of the pre-post assessment of students' listening performance

\begin{tabular}{|c|c|c|c|c|c|c|c|}
\hline Data source & \multicolumn{2}{|c|}{ Rank } & $\mathbf{N}$ & $\begin{array}{l}\text { Mean } \\
\text { Rank }\end{array}$ & $\begin{array}{l}\text { Sum of } \\
\text { Ranks }\end{array}$ & $\begin{array}{c}\text { Z- } \\
\text { Value }\end{array}$ & Sig. \\
\hline \multirow{2}{*}{$\begin{array}{c}\text { Guessing the } \\
\text { meaning of the new } \\
\text { words from their } \\
\text { context }\end{array}$} & \multirow{2}{*}{$\begin{array}{l}\text { Post- } \\
\text { pre }\end{array}$} & Negative & $\mathbf{0}$ & 0.00 & 0.00 & \multirow{2}{*}{3.771} & \multirow{2}{*}{0.000} \\
\hline & & Positive & 15 & 8.00 & 120.00 & & \\
\hline \multirow{2}{*}{$\begin{array}{l}\text { Listening for specific } \\
\text { information }\end{array}$} & \multirow{2}{*}{$\begin{array}{l}\text { Post- } \\
\text { pre }\end{array}$} & Negative & 0 & 0.00 & 0.00 & \multirow{2}{*}{3.520} & \multirow{2}{*}{0.000} \\
\hline & & Positive & 15 & 8.00 & 120.00 & & \\
\hline \multirow{2}{*}{$\begin{array}{l}\text { Identifying the main } \\
\text { idea in the spoken } \\
\text { discourse }\end{array}$} & \multirow{2}{*}{$\begin{array}{l}\text { Post- } \\
\text { pre }\end{array}$} & Negative & $\mathbf{0 g}$ & 0.00 & 0.00 & \multirow{2}{*}{3.535} & \multirow{2}{*}{0.000} \\
\hline & & Positive & 15 & 8.00 & 120.00 & & \\
\hline \multirow{2}{*}{$\begin{array}{l}\text { Recognizing the } \\
\text { letter sound } \\
\text { association }\end{array}$} & \multirow{2}{*}{$\begin{array}{l}\text { Post- } \\
\text { pre }\end{array}$} & Negative & $\mathbf{0}$ & 0.00 & 0.00 & \multirow{2}{*}{3.502} & \multirow{2}{*}{0.000} \\
\hline & & Positive & 15 & 8.00 & 120.00 & & \\
\hline \multirow{2}{*}{ Making inferences } & \multirow{2}{*}{$\begin{array}{l}\text { Post- } \\
\text { pre }\end{array}$} & Negative & $\mathbf{0}$ & 0.00 & 0.00 & \multirow{2}{*}{3.493} & \multirow{2}{*}{0.000} \\
\hline & & Positive & 15 & 8.00 & 120.00 & & \\
\hline total & $\begin{array}{l}\text { Post- } \\
\text { pre }\end{array}$ & Negative & $\mathbf{0}$ & 0.00 & 0.00 & 3.441 & 0.001 \\
\hline
\end{tabular}

From the previous Table (11) it is clear that the $\mathrm{Z}$ values of the test and test skills as a whole were $(3.771,3.520,3.535,3.502$, 3.493 , 3.441) respectively and the corresponding probability values of $(0.000$, $0.000,0.000,0.000,0.000,0.001)$. The mean rank for each test and test skills as a whole $(8.00,8.00,8.00,8.00,8.00$ and 8.00$)$, 
respectively, were statistically significant differences between the average ranks of students in the pre and post applications. $(0.00,0.00,0.00,0.00,0.00,0.00)$, which is greater than the tribal average.

\section{Secondly, Calculating the Effect Size}

Al-Saeed (1997, p. 135) and Salama (2004, p.

8) explained that, briefly, the effect size measures the effect of the independent variable on the dependent variable. The effect size depends on the type of statistical test; the corresponding effect size for each statistical test is calculated using the appropriate equation.

One of the suitable ways to calculate the effect size in the case of non- parametric statistics is to use the following equation:

$$
R=\frac{Z}{\sqrt{n}}
$$

In this equation, $\mathrm{R}$ represents the effect size, $\mathrm{Z}$ represents the test statistic, $\mathrm{n}$ represents the number of views. The $\mathrm{R}$ value is judged in the light of the following criteria:

- From 0.1: to less than 0.3 the effect size is small.

- From 0.3: to less than 0.5 the effect size is moderate.

- $\quad 0.5$ and more the effect size is large.

- Accordingly, the effect size of the Webbased learning program in the EFL Listening Skills Test was calculated and the results were shown in the table (9) below:

Table (9) The Effect Size of the Program in the EFL Listening Skills

\begin{tabular}{|c|c|c|c|}
\hline Skills & $\mathbf{N}$ & $\overline{\mathbf{Z}}$ & $\overline{\mathbf{R}}$ \\
\hline Guessing the meaning of the new words from their context & \multirow{6}{*}{30} & 3.771 & 0.688 \\
\hline Listening for specific information & & 3.520 & 0.643 \\
\hline Identifying the main idea in the spoken discourse & & 3.535 & 0.645 \\
\hline Recognizing the letter sound association & & 3.502 & 0.639 \\
\hline Making inferences & & 3.493 & 0.638 \\
\hline Total & & 3.441 & 0.628 \\
\hline
\end{tabular}

The above table shows that $\mathrm{R}$ values for test and test skills as a whole were $(0.688,0.643$, $0.654,0.639,0.638 .0 .628)$ respectively and all these values are greater than 0.5 indicating that the web-based learning program has a large effect on improving the students' levels in each skill of the test and the test as a whole.

\section{Thirdly, Calculating the Effectiveness of the Program in the Test}

The effectiveness of the Web-based learning program in the EFL Listening Skills Test was calculated using Black's formula and the results were shown in the Table (10) below: 
Table (10) Black's Moderator Gain Percent to Measure the Effectiveness of the Program

\begin{tabular}{c|c|c|c|c|c}
\hline \hline \multirow{2}{*}{ Skill } & \multirow{2}{*}{$\begin{array}{c}\text { Full } \\
\text { Mark }\end{array}$} & \multicolumn{2}{|c|}{ Mean Scores } & \multirow{2}{*}{$\begin{array}{c}\text { Black's ratio } \\
\text { Value }\end{array}$} & \\
\cline { 3 - 4 } & & Pre & Post & & Significance \\
\hline First & 6 & 0.80 & 4.93 & 1.48 & effective \\
\hline Second & 6 & 0.27 & 5.07 & 1.64 & effective \\
\hline Third & 6 & 0.93 & 5.33 & 1.60 & effective \\
\hline Fourth & 6 & 0.27 & 4.53 & 1.46 & effective \\
\hline fifth & 6 & 0.40 & 5.33 & 1.70 & effective \\
\hline Total & 30 & 2.67 & 25.20 & 1.58 & effective \\
\hline \hline
\end{tabular}

It is noted from the above table that the Webbased Learning program has educationally acceptable effectiveness in each skill of test and test as a whole, because the Black's ratio Value of each skill or test as a whole is greater than 1.2.

\section{Discussion}

The following lines concentrate on discussing and analyzing the results of students' EFL listening skills test.

\section{Students' EFL Listening Skills}

The first question investigated whether the suggested program based on web-based learning would develop the first-year secondary school students' EFL Listening Skills. This online course was found effective and helpful in developing listening skills.

Results of the in-depth analysis of students' scores also demonstrated a significant improvement in the EFL listening skills. Checking students' answers to the post-test questions and their responses in the discussion showed that their listening skills noticeably improved.

In addition, the effectiveness of the program was reflected in high scores that the students obtained after being exposed to the program. The large-size effect provided a confirmation that the program resulted in improvement in the students' performance in the listening skills.

Furthermore, the five listening skills were developed and improved because of the activities and the exercises included in the program and the enrichment websites suggested within it. The greatest effect of this program was on the listening skill of (making inferences) as $66.6 \%$ of the students got the full marks. This resulted from the repetition of listening to the scripts which supported their understanding and helped them to make inferences. The listening skill which came second in the level of development and 
improvement was the third skill (identifying the main idea in the spoken discourse) as $60 \%$ of the students got the full marks. The activities and exercises the students practiced were the reasons for the development of this skill. The skill of identifying the main idea was stressed through many activities that asked students to extract the main idea of the completely listening task. These activities were performed online and the students had opportunities to discuss online their thoughts and to discuss with their classmates and their teacher evidence that supported their answers.

The listening skill which came third was (listening for specific information) as 53.3\% of the students got the full marks. The skill of finding specific information was stressed through many activities that require students to think of all the details related to the main topic of the text and to respond to multiplechoice questions. The fourth one was (guessing the meaning of the new words from their context) as $47 \%$ of the students got the full marks. The students were encouraged to guess the meaning of the new words because the tasks were timed and they didn't have enough time to use the dictionary to look up each difficult word. Although this program had a positive effect on the development of the skill of (recognizing the letter sound association), it was the least effect compared to the other skills as $33.3 \%$ of the students got full marks. Recognizing the letter sound association was a difficult skill and the development was the least, maybe, because students didn't have good background about phonetics

The findings of the current study is consistent with the results of other studies conducted by Jones (2002), Wong (2005) and Bear (2008) in which the students' listening skills improved clearly through using web resources. The current study and the previous studies agreed that learning materials provided on the web are very effective in developing listening because they are attractive to the learners and they are, also, interesting so the learners do not feel bored.

As a main component of the current program You Tube videos were effective in developing listening skills, this finding was found also by Cass (2007), Batra (2008) and Badal (2008) who assured the positive influence of You Tube videos on developing listening skills because while listening to digital audio or watching a video clip, learners have the opportunity to pause at will, and listen and read a transcript. Moreover, learners can get instant feedback on what they have done. Another study conducted by Wong (2010) found that web-based learning 
and cooperative learning contributed to developing listening and speaking skills.

\section{References}

Abdel Latif, M., M. (2002).The effect of graded rates of delivery on listening comprehension among English Department student. Unpublished M.A. Thesis. Faculty of Education. Al-Azhar University.

Abdelhafez, A.,M.(2006). The Effect of a Suggested Training Program in Some Metacognitive Language Learning Strategies on Developing Listening and Reading Comprehension of university EFL Students. PhD Dissertation. Faculty of Education, Minia University.

Al-Hariree, A. M. (2004).The Effect of Some Metacognitive Strategies on Developing Listening Comprehension Skills of Secondary School Students. Unpublished M.A. Thesis, Faculty of Education, Zagazig University.

Al-Jarf, R. S. (2000). Effect of online learning on struggling ESL college writers. Riyadh, Saudi Arabia: King Saud University.

Almekhlafi, A. (2006). The effect of computer assisted language learning (CALL) on United Arab Emirates EFL school students' achievement and attitude. Journal of Interactive Research, 17(2), 121-142.

Alsied, S., M. \& Pathan, M., M. (2013) The Use of Computer Technology in EFL Classroom: Advantages and Implications International Refereed \& Indexed Journal of English Language \& Translation Studies, 1, Issue: 1, 1, www.eltsjournal.org Issue.

Amin, A., Aly, M. \& Amin, M.(2011). A Correlation Study between EFL Strategic Listening and Listening Comprehension Skills among Secondary School Students. Faculty of Education, Benha University.

Amin, A., Aly, M. \& Amin, M.(2011). The effectiveness of using an explicit language learning strategy-based instruction in developing secondary school students' EFL listening comprehension skills. Faculty of Education, Benha University.

Arnold, W. (2005). Listening for Young learners. British Council Teaching English. Available online at: http://www.teachingenglish.org.uK/think/ listen/_yl.shtm1. Retrieved on May 7,2012. Badal,Sharon.(2008). Swimming Upstream: A life saving guide to short film distribution. Boston: Focal Press. 
Batra, N. (2008). Digital Freedom: How much can handle? Lanham, MD: Rowman\& Little field.

Beare, K. (2008).YouTube in the Classroom. Available online at: About.com: English as $2^{\text {nd }} \quad$ Language Website: http://esl.about.com/od/listening lesson plans /a/youtube.htm. Retrieved on June, 2012.

Callahan Cory, Saye John, \& Brush Thomas (2013). Designing web-based educative curriculum materials for the social studies. Contemporary Issues in Technology and Teacher Education, 13(2), 126-155.

Canning-Wilson, C. (2000). E-learning, eteaching, e-assessment: Aspects of course design for on-line web based courses used with EFL/ESL learners. Abu Dhabi, U.A.E.: Cert-Higher Colleges of Technology (ERIC Document Reproduction Service No. ED 449788).

Cass, J. (2007). Strategies and Tools for Corporate blogging. Boston: Allyn \& Bacon.

Duffy, P. (2008). "Engaging the YouTube Google-Eyed Generation: Strategies for Using Web 2.0 in Teaching and Learning." The Electronic Journal of e-Learning, 6, (2), 119 - 130, available online at www.ejel.org
Elkeles, C. (2003). Listening Games and Activities. Available online at: http://www.articlesforeducators.com/default. asp. Retrieved on May 7,2012.

Eltawila, M. (2009).The Neglect of Listening Activities Among Egyptian Preparatory School EFL Teachers. M.A. Thesis, Tanta University. Tanta. Egypt .Available online at: www.proquest.com. Retrieved on August 22, 2013.

Ghaderpanahi , L. (2012). Using Authentic Aural Materials to Develop Listening Comprehension in the EFL Classroom. English Language Teaching, 5, (6).Available online at: www.ccsenet.org/elt.

Jones, L., C. (2003). Supporting Listening Comprehension and Vocabulary Acquisition with Multimedia Annotations: The Students' voice. CALICO Journal, 27(1),41-65.

Jossey-Bass. \& Khan, B. H. (2001): Webbased Training. Educational Technology Publications.

Kung, S-C. \& Chuo, T-W. (2002). Students' perceptions of English learning through ESL/EFL websites. TESL-EJ. 6, (1), Retrieved May 12, 2013, from http://wwwwriting. berkeley.edu/tesl-ej/ej21/a2.html Learning. The Quarterly Review of Distance Education, 
Murray, D. \& Mcpherson, P. (2004). Using the Web to support language learning. National Centre for English Language Teaching and Research, Macquarie University, Sydney NSW 2109.

Mousavi, S., A.\& Iravani, H. (2012). The Effect of Authentic Versus Non-authentic Aural Materials on EFL Learners' Listening Comprehension. English Language and Literature Studies , 2, (1). Available online at: www.ccsenet.org/ells.

Rost, M. (2002). Teaching and Researching Listening. London: Longman.

Sabet, M.,K. \& Mahsefat, H. (2012). The Impact of Authentic Listening Materials on Elementary EFL Learners' Listening Skills. International Journal of Applied Linguistics \& English Literature, ISSN 2200-3452, 1, (4).

Schilling,D.(2002). Be an Effective Listener! Available online at http://www.womensmedia.com/seminarlistening.htm1. Retrieved on May 7, 2012.

Soliman, E., R., O. (2012). The Effect of Using the Integrated Strategy on Developing some Listening Skills in English Language for Secondary Stage Students. Unpublished M.A. Thesis, Institute of Educational Studies, Cairo University.

Son, J-B. (2007). Learner experiences in Web-based language learning. Computer Assisted Language Learning, 20(1), 21-36.

SZE, P., M-M. (2006). Developing Students' Listening and Speaking Skills Through ELT Podcasts. Education Journal. $34,(2)$.

Tompkins ,G. E.(2005). Language arts: Patterns of Practice (6th Ed.). Upper Saddle River, NJ: Pearson Prentice-Hall.

Vandergrift, L. (2006). Second Language Listening Ability or Language Proficiency?, The Modern Language Journal, 90, 1, 2006.

Vo, Y. (2013). Developing extensive listening for EFL learners using Internet resources. Hawaii Pacific University TESOL Working Paper Series 11, 29-51.available online at: http://www.hpu.edu.

Waescher, M. \& Kem, R. (2005).Networkbased Language Teaching: Concepts and Practice . Cambridge: Cambridge University Press.

Wong, J. (2005). English Listening Courses: A case of Pedagogy lagging behind Technology[Electronic Version ].Electronic Journal of Foreign Language Teaching. 2(1), 41-65. 
Zapata, G. \& Sagarra, N. (2007). Call on hold: The delayed benefits of an on-line workbook on L2 vocabulary. Computer Assisted Language Learning, 20(2), 153-171. Zapata, G. C. \& Sagarra, N. (2007). CALL on hold: The delayed benefits of an online workbook on L2 vocabulary learning. Computer Assisted Language Learning, 20(2), 153-171.

Zeng, Z. \& Murphy, E. (2007). Tensions in the Language Learning Experiences and Beliefs of Chinese Teachers of English as a Foreign Language (electronic version).TESLEJ, 10(4), A-1, 44.

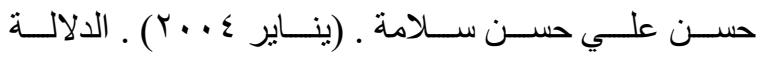
الإحصـائية و الدلالـة العلميـة في البحوث التربويـة ـ المجلـة

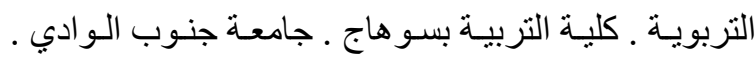

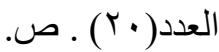
رضا مسعد السعيد ـ (199VV) ـ الإحصاء النفسي و التربوي (نماذج و أساليب حديثة) . الإسكندرية: مطبعة الجمهورية. 